Декабрьская Я.Н. Магистрант Мининского университета

Крайнова Ольга Сергеевна,

канд. экон. наук, доц., зав. кафедрой туризма филиала ЧОУВО «Московский университет им. С.Ю.Витте» в г. Нижнем Новгороде (Нижний Новгород)

\title{
ВОДНЫЙ ТРАНСПОРТ В РАЗВИТИИ ИНФРАСТРУКТУРЫ ТУРИЗМА НИЖНЕГО НОВГОРОДА
}

Водный транспорт является одним из древнейших. С давних времен множество людей отправлялись в путешествия, с целью познания мира и открытия новых территорий, с торговыми, дипломатическими, военными, религиозными и иными миссиями. В настоящее время водный транспорт становится все менее востребованным.

Проанализировав итоги пассажирской навигации судоходной компании «Волжское пароходство» за период с 2008 по 2011 год, можно сделать вывод, что круизные маршруты стали менее востребованы.

Таблица 1

Итоги работы судоходной компании «Волжское пароходство»

в 2008-2011 году

\begin{tabular}{|l|l|l|}
\hline Период навигации & $\begin{array}{l}\text { Общее количество } \\
\text { человек (тыс.чел) }\end{array}$ & $\begin{array}{l}\text { Количество человек } \\
\text { на круизных } \\
\text { маршрутах (тыс. чел) }\end{array}$ \\
\hline апрель-октябрь 2008 & 454 & 252 \\
\hline апрель-октябрь 2009 & 359 & 234 \\
\hline апрель-октябрь 2010 & 383 & 239 \\
\hline апрель-октябрь 2011 & 368 & 223 \\
\hline
\end{tabular}

По данным судоходной компании «Волжское параходство» в 2012 году: «В оперативное управление ООО «ВодоходЬ» переданы четырехпалубные круизные теплоходы Волжского пароходства, а также 
малый пассажирский флот: скоростные суда типа «Метеор» и прогулочные теплоходы.

Реорганизация проводится в целях укрупнения круизного дивизиона холдинга. Это позволит оптимизировать управление активами, а также откроет больше возможностей для повышения стандартов качества туристического продукта и обслуживания на борту.» [8]

После того как пассажирские суда отдали ООО «ВодоходЪ», количество пассажиров сократилось. Навигация длилась с 29 апреля 2013 по 20 октября 2013, за это время на круизные теплоходы было принято 112 тысяч клиентов, что почти в 2 раза меньше, чем во время навигации 2011 года. [1]

Анализируя внутренний водный транспорт, можно сделать вывод, что не востребован он по нескольким причинам.

Во-первых, безопасность- один из важнейших критериев, который учитывает каждый турист, при организации своего путешествия. Все чаще и чаще мы слышим о тех или иных кораблекрушениях и несчастных случаях на воде. Некоторые специалисты при анализе таких трагедий ссылаются на год выпуска того или иного судна, но не всегда дело только в этом. Например, двухпалубному дизель-электроходу "Булгария", затонувшему в июле 2011года, необходим был капитальный ремонт. "По версии экспертов, причиной кораблекрушения стало плохое техническое состояние теплохода. Судно служило 56 лет и в последний раз проходило капитальный ремонт в 1980 году. По некоторым данным, многие члены экипажа работали без трудовых договоров. Владеющая теплоходом компания "Камское речное пароходство" сдавала судно в аренду ООО "Бриз", которое передало его в пользование казанскому ООО "АргоРечТур". По данным некоторых источников, из-за запутанной схемы аренды было неясно, кто должен заниматься ремонтом судна. При этом "АргоРечТур" организовывало круизные туры, не имея на это лицензии. [3] 
В августе 2013 года однопалубный теплоход «Полесье-8», 1989 года постройки, совершавший круиз по маршруту Омск-Ачаир (Ачаирский монастырь), столкнулся с грузовой баржей на реке Иртыш в районе посёлка Новая Станица Ленинского округа города Омска. «В УМВД по Омской области "Интерфаксу-Сибирь" сообщили, что человек, находившийся за штурвалом теплохода, был нетрезвым.» [2]

Просматривая сводки событий с информацией о кораблекрушениях турист получает негативную рекламу о водном транспорте.

Во-вторых, стоимость путешествия велика, и не каждый человек сможет позволить себе круиз. Например, цены на путешествие из Нижнего Новгорода в Астрахань и обратно в Нижегородской судоходной компании «ВодоходЂ» начинаются от 43 тысяч рублей с человека за 12 дней. Такой же маршрут в круизной компании «Инфофлот» стоит от 38 тысяч рублей с человека. Соответственно, в жаркие месяцы стоимость путешествия выше, чем в начале и конце сезона.

Туристы с достатком выше среднего, предпочтут отдых за ту же стоимость, но с более комфортными условиями. Например, турпродукт «Прованс - Лазурный берег - отдых в Испании» на 12 дней турист может приобрести за 30 тысяч рублей.

В-третьих, закрываются маршруты экскурсионного назначения (в часности, судна на подводных крыльях):

Нижний Новгород - Макарьев (бывш. село Макарьево). Вниз по Волге. Обслуживался судами на подводных крыльях типа "Ракета", "Восход". Маршрут пользовался популярностью у туристов, посещающих Макарьевский монастырь. Закрыт в 2008 году.

Нижний Новгород - Чкаловск - Юрьевец. Вверх по Волге. (был закрыт в 2005 году с формулировкой "нерентабелен"). Обслуживался судами на подводных крыльях типа "Метеор".

Нижний Новгород - Ярославль - Нижний Новгород (открыт в августе 2006, закрыт в 2006) 
Нижний Новгород - Сокольское - открыт и закрыт в 2007 году, отработав неделю.

Пассажирские перевозки на территории Нижнего Новгорода и области осуществляет компания ВолгаФлот. В 2009 году закрыты практически все местные и пригородные перевозки, за исключением Нижний Новгород - Бор (водоизмещающий флот) и Нижний Новгород - затон им. Калинина (скоростной флот). Причина - отсутствие средств в бюджете на дотацию убытков. По состоянию на 2013 год местных перевозок на реке в "волжской столице" нет. [5]

Не у многих есть возможность взять отпуск летом, чтобы на неделю или две пройтись на теплоходе вдоль берегов российских рек. Но судна на подводных крыльях более мобильные и могут в короткие сроки доставить туристов по водной «дороге» в ближайшие города. Соответственно, люди более занятые смогут превратить свой отдых на день или два в речное путешествие. Что так же повысит рентабельность пассажирского флота.

И наконец, отсутствие рекламы- эта причина не основная, но она существенно затрудняет процесс осведомления потенциальных туристов о возможности совершить путешествие на водном транспорте.

Таким образом, если участники организации процесса будут более ответственно относится к безопасности пассажиров, организуя отдых туристов с соблюдением соответствующих законов и правил, можно предположить, что аварий на воде будет меньше, а у туристов не будет недоверия к водному транспорту. Возможно, если уменьшить стоимость путешествий за счет предоставления скидок, водные путешествия приобретут большую популярность. Если открыть туры экскурсионного назначения, которые пользовались популярностью ранее, то скорее всего люди с большой занятостью, но имеющие желание отдохнуть в путешествии на водном транспорте проявят интерес к турам на водных крыльях. Если более серьезно подойти к продвижению водных туров и организовать рекламу не только в интернете на малопосещаемых сайтах, но и другим 
способом, то потенциальные туристы смогут узнать о возможности путешествия по водным путям, что повысит рентабельность водного транспорта.

\begin{abstract}
Список литературы
1. ВодоходЂ/Круизы и путешествия [Электронный ресурс] : полная версия. Поиск круиза/Поиск речного круиза в навигацию 2014 года URL: http://www.vodohod.com/)
\end{abstract}

2. Интерфакс [Электронный ресурс] : мобильная версия. Сюжеты/ Катастрофы на воде/ Катастрофа теплохода на Иртыше URL: http://www.interfax.ru/

3. Исторический форум "Мир истории" [Электронный ресурс] : полная версия. События в России / Главные новости, происшествия / 10 июля на Волге затонул пассажирский теплоход "Булгария" URL: http:/forumhistory.ru/

4. Круизная компания Инфофлот [Электронный ресурс] : полная версия. Маршруты речных круизов URL: http:/www.infoflot.com/

5. Общественный транспорт [Электронный ресурс] : полная версия. Водный транспорт/Речной транспорт Нижегородской области URL: http://www.transp.nnov.ru/

6. Онлайн путеводитель [Электронный ресурс] : полная версия. Европа/Россия/Нижний новгород/Транспорт/Водный транспорт в Нижнем Новгороде URL: http://www.arrivo.ru/

7. Путешествия.ру/Туристическая компания [Электронный ресурс] : полная версия. Туры/ Экскурсионные туры/ Результат поиска URL: http://www.puteshestvuy-ru.ru/

8. Судоходная компания Волжское пароходство [Электронный ресурс] : полная версия. Новости / Судоходная компания "Волжское пароходство" 
подвела итоги работы в 2008 году, Итоги пассажирской навигации Волжского пароходства 2011 года URL: http://www.volgaflot.com/ 9. Туристический бизнес [Электронный ресурс] : полная версия. Турагентство / Перевозки /Водный транспорт в туризме URL: http://tourfaq.net 